Research Article

www.ijrap.net

\title{
HIGH PERFORMANCE LIQUID CHROMATOGRAPHIC METHOD FOR SIMULTANEOUS QUANTITATION OF BETULINIC ACID AND URSOLIC ACID FROM DRIED STEM BARK POWDER OF MIMUSOPS ELENGI LINN.
}

\author{
Vidya Dighe, Dhanashri Mestry*
}

Chemistry Department, Ramnarain Ruia College, Matunga, Mumbai, Maharashtra, India

Received on: 14/10/13 Revised on: 06/11/13 Accepted on: 10/12/13

\author{
*Corresponding author \\ E-mail: dhanashrimestry@gmail.com \\ DOI: $10.7897 / 2277-4343.04625$ \\ Published by Moksha Publishing House. Website www.mokshaph.com \\ All rights reserved.
}

\section{ABSTRACT}

Mimusops elengi Linn., commonly called as bakul, is found all over India. It is a famous plant for its fragrant flowers. Each part of this plant possesses medicinal properties. A simple and reverse phase high performance liquid chromatographic (HPLC) method has been developed for the quantitative determination of betulinic acid and ursolic acid which are triterpene acids present in stem bark of Mimusops elengi Linn. The developed HPLC method was validated by using International Conference on Harmonization (ICH) guidelines. The developed HPLC method was found to be rapid, simple and precise and provided good resolution of betulinic acid and ursolic acid from other phytoconstituents present in the dried stem bark powder of Mimusops elengi Linn.

Keywords: Mimusops elengi Linn., betulinic acid, ursolic acid, triterpene acids, High performance liquid chromatography, Sapotaceae

\section{INTRODUCTION}

Mimusops elengi Linn., is a medicinal plant belonging to family Sapotaceae. It is a small to large evergreen tree which grows up to $15 \mathrm{~m}$ in height and has many medicinal properties. The stem bark of Mimusops elengi Linn. is reported to have wound healing ${ }^{1,2}$ anti-oxidant $^{3-5}$, anti-hyperglycaemic ${ }^{3,6}$, anti-urolithiatic ${ }^{4}$ and antibiotic activity ${ }^{7}$. The stem bark is reported to contain many phytochemicals such as $\beta$-amyrin, bassic acid, betulinic acid, lupeol, taraxerone, taraxerol, ursolic acid, $\alpha-$ spinasterol, $\beta$-D- glucoside of $\beta$-sitosterol and quercitol ${ }^{8}$.Betulinic acid andUrsolic acid are triterpene acids. Betulinic acidis reported to slow down the activity of the human immunodeficiency virus (HIV), induce apoptosis and cell death in melanoma cells without impacting healthy tissue ${ }^{9}$. Betulinic acid is useful for its pharmacological properties, especially in the treatment of diarrhoea, dysentery and cholera ${ }^{9}$.Ursolic acid has several important biological activities like anti-inflammatory and antitumor properties. It is effective for in vitro reduction of growth of a variety of cancer cells ${ }^{11}$. It also possesses hepatoprotective, anti-ulcer, hypolipidemic and antiatherosleroic potential ${ }^{12}$. It is significant antitumorigenesis and antioxidant agent ${ }^{13}$.A reverse phase HPLC method has been developed for separation of three triterpene acids betulinic acid, ursolic acid and oleonic $\mathrm{acid}^{14}$. The separation was carried on $\mathrm{C} 18$ silica Lichrospher 100RP-18 column ( $125 \mathrm{~mm} \times 4 \mathrm{~mm}, 5 \mu \mathrm{m})$. The detection was done at $\lambda=225 \mathrm{~nm}$. Another HPLC method has been reported for identification of betulinic acid and ursolic acid from apple ${ }^{15}$. The separation was achieved on Develosil RP aqueous column $(250 \mathrm{~mm} x$ $4.6 \mathrm{~mm}, 5 \mu \mathrm{mPhenomenex})$. The detection was done at $\lambda=210 \mathrm{~nm}$. However, no HPLC method is reported for the simultaneous quantitation of betulinic acid and ursolic acid from stem bark of Mimusops elengi Linn. Considering medicinal properties of betulinic acid and ursolic acid, in the present research work, a high performance liquid chromatographic method was developed for the separation and quantitation of betulinic acid and ursolic acid. Thus, precise and accurate HPLC method has been developed and validated using International Conference on Harmonization (ICH) guidelines for simultaneous determination and quantitation of betulinic acid and ursolic acid from dried stem bark powder of Mimusops elengi Linn.

\section{MATERIALS AND METHODS}

Experimental Reagents

All the solvents used in the analysis were of HPLC grade. Methanol (purity- $99.7 \%$ ), acetonitrile (purity- $99.8 \%$ ) and distilled water used were procured from LiChrosolv Merck, India.

\section{Reference Standards}

The reference standards betulinic acid (purity $\geq 98.0 \%$ HPLC Grade) and ursolic acid (purity $\geq 90.0 \%$ HPLC Grade) were purchased from Sigma-Aldrich Chemie GmbH (Aldrich Division, Steinbeim, Germany).

\section{Plant Material}

The stem bark of Mimusops elengi Linn., was collected from Keshav Srushti, Mumbai, India. Herbarium of the plant was prepared and authenticated from Botanical Survey of India (BSI), Pune, India. The herbarium voucher specimen number was DHMMIE3. The stem barks of Mimusops elengi Linn., were washed with water to remove soil particles, dried at $45 \pm 2^{\circ} \mathrm{C}^{16}$, powdered and then sieved through BSS mesh no. 85 and stored in an airtight container at room temperature $\left(25 \pm 2^{\circ} \mathrm{C}\right)$. 
Preparation of Solutions

Preparation of stock standard solutions of betulinic acid and ursolic acid

Stock solutions of betulinic acid and ursolic acidwith concentration of $1000.0 \mu \mathrm{g} / \mathrm{mL}$ were prepared.

\section{Preparation of sample solution}

About $1.0 \mathrm{~g}$ of finely powdered stem bark powder of Mimusops elengi Linn., was extracted in $10 \mathrm{~mL}$ of methanol The extract was passed through $0.45 \mu \mathrm{m}$ nylon filters (Millipore) before the analysis.

\section{HPLC Conditions}

HPLC analysis was performed using Shimadzu UFLC Prominence chromatograph, equipped with binary gradient pump (LC-20AD), and fitted with auto sampler (SIL-20 AC HT) and oven (CTO-20 AC). A reversed phase, phenomnex RP $\mathrm{C}_{18}(250 \mathrm{mmx} 4.6 \mathrm{~mm}, 5 \mu \mathrm{m})$ column was used for the chromatographic separation. The detection was done using PDA detector (SPD-M20A). LC solution chromatographic software was used for data acquisition.The mobile phase used is water and acetonitrile with the volume ratio of $88: 12$. The injection volume was $10 \mu \mathrm{L}$. The detection was done using PDA detector (SPD-M20A) at $\lambda=210 \mathrm{~nm}$.

\section{Method Validation}

\section{Linearity}

Preparation of calibration curve of betulinic acid and ursolic acid

Each standard solutions of betulinic acid in the concentration range of $1.0 \mu \mathrm{g} / \mathrm{mL}$ to $750.0 \mu \mathrm{g} / \mathrm{mL}$ and 10.0 $\mu \mathrm{L}$ of each standard solutions of ursolic acid in the concentration range of $1.0 \mu \mathrm{g} / \mathrm{mL}$ to $500.0 \mu \mathrm{g} / \mathrm{mL}$ were injected in triplicates into the chromatographic system in triplicate, under the optimized chromatographic conditions. The peak areas were recorded for each injected concentration of betulinic acid solution. The calibration curves of both betulinic acid and ursolic acid were obtained by plotting graphs of mean peak areas vs. corresponding concentrations. The results listed in Table 1.

\section{Limit of Detection (LOD) and Limit of Quantitation (LOQ)}

The limit of detection (LOD) and limit of quantitation (LOQ) were determined at signal to noise ratios of $3: 1$ and 10:1, respectively. The LOD and LOQ values obtained for both the components are listed in Table 1 .

\section{System Suitability}

System suitability was carried out to verify that resolution and reproducibility of the system were acceptable for the analysis. Mixture of standard solution of betulinic acid with concentration of $500.0 \mu \mathrm{g} / \mathrm{mL}$ and ursolic acid with concentration of $100.0 \mu \mathrm{g} / \mathrm{mL}$ was injected in six replicates under optimized chromatographic conditions. The values of percent relative standard deviations of peak area and retention time of standards were taken as an indicator of system suitability and are less than 2, indicating that the method is suitable for analysis.

\section{Precision}

The method was validated in terms of repeatability and intermediate precision. The repeatability was evaluated by triplicate analysis of three sample solutions prepared separately. The intermediate precision of the method was evaluated by analyzing three sample solutions in triplicate on three different days, under the optimized chromatographic conditions. The peak areas of betulinic acid and ursolic acid were recorded. The precision results were expressed as percentage relative standard deviations of peak areas of betulinic acid and ursolic acid and are listed in Table 1. The results indicate that the proposed method is precise and reproducible.

\section{Robustness}

The robustness of the method is a measure of method's capacity to remain unaffected by small deliberate variations in the method parameters and provides an indication of reliability of the method during normal usage. The mobile phase composition was altered to acetonitrile: water $(89.0: 11.0 \mathrm{v} / \mathrm{v})$ and acetonitrile: water $(88.0: 12.0 \mathrm{v} / \mathrm{v})$ and flow rate was changed to $0.9 \mathrm{~mL} / \mathrm{min}$ and $1.1 \mathrm{~mL} / \mathrm{min}$. The resolution between betulinic acid and ursolic acid and tailing factors of both components from sample solution did not change much due to alteration in the methods. The amounts of betulinic acid and ursolic acid from dried stem bark powder of Mimusops elengi Linn. obtained by altered method and that obtained by normal method was found to be similar. The modifications did not affect the system suitability criteria. However, slight variation in the retention time was observed, which was due to changes made in the mobile phase composition and flow rate. From the observations, it was concluded that the method is robust as the above mentioned deliberate changes made in the method did not affect the results.

\section{Assay procedure}

The developed and validated HPLC method was used for quantitation of betulinic acid and ursolic acid from the methanolic extract of dried stem bark powder of Mimusops elengi Linn. Amounts of betulinic acid and ursolic acid present in the sample solution were determined from the calibration curve, by using the peak area of betulinic acid and ursolic acid in the sample.

\section{Recovery}

The accuracy of the method was established by performing recovery experiment by using standard addition method at three different levels. The results of accuracy are listed in Table 2 .

\section{RESULTS AND DISCUSSION}

Different mobile phases were tried for simultaneous HPLC separation of betulinic acid and ursolic acid from other components of the dried stem bark powder of Mimusops elengi Linn. and good separation was achieved by using water: acetonitrile $(88.0: 12.0 \mathrm{v} / \mathrm{v})$ as mobile phase. Detection was carried out at $\lambda=210 \mathrm{~nm}$ as both betulinic acid and ursolic acid showed maximum response at this wavelength. 
Vidya Dighe et al / Int. J. Res. Ayurveda Pharm. 4(6), Nov-Dec 2013

Table 1: Method validation data for simultaneous quantitation of betulinic acid and ursolic acid

\begin{tabular}{|c|c|c|}
\hline \multirow{2}{*}{ Parameters } & \multicolumn{2}{|c|}{ Results } \\
\cline { 2 - 3 } & Betulinic acid & Ursolic acid \\
\hline Linear range $(\mathrm{n}=3)(\mu \mathrm{g} / \mathrm{mL})$ & $1.0-750.0$ & $1.0-500.0$ \\
\hline Correlation coefficient $(\mathrm{r})$ & 0.999 & 0.999 \\
\hline LOD $(\mu \mathrm{g} / \mathrm{mL})$ & 0.30 & 0.30 \\
\hline LOQ $(\mu \mathrm{g} / \mathrm{mL})$ & 1.0 & 1.0 \\
\hline System suitability (\%R.S.D.) & Less than 2 & Less than 2 \\
\hline $\begin{array}{c}\text { Repeatability (\% R.S.D.) }(\mathrm{n}=3) \\
(\text { On the same day) }\end{array}$ & 0.88 & 0.94 \\
\hline $\begin{array}{c}\text { Intermediate precision }(\% \text { R.S.D.) }(\mathrm{n}=9) \\
\text { (For three successive days ) }\end{array}$ & 0.96 & 0.99 \\
\hline Assay $(\mathrm{mg} / \mathrm{g})$ & 4.6523 & $1.3067 \mathrm{~m}$ \\
\hline
\end{tabular}

Table 2: Results of recovery study for simultaneous HPLC quantitation of betulinic acid and ursolic acid from methanolic extract of dried stem bark powder of Mimusops elengi Linn.

\begin{tabular}{|c|c|c|c|c|}
\hline Level & $\begin{array}{l}\text { Amount of } \\
\text { sample (g) }\end{array}$ & $\begin{array}{c}\text { Amount of standard added to } \\
\text { sample (mg) }\end{array}$ & $\begin{array}{c}\text { Mean amount of standard found } \\
(\mathbf{m g}) \pm \text { S.D. }\end{array}$ & $\begin{array}{l}\text { Percent } \\
\text { recovery }\end{array}$ \\
\hline \multicolumn{5}{|c|}{ Betulinic acid } \\
\hline 0 & 1.005 & 0.0000 & $4.6365 \pm 0.0488$ & \multirow[t]{4}{*}{97.71} \\
\hline 1 & 1.003 & 0.1000 & $4.7331 \pm 0.0325$ & \\
\hline 2 & 1.002 & 0.2000 & $4.8258 \pm 0.0305$ & \\
\hline 3 & 1.005 & 0.3000 & $4.9313 \pm 0.0356$ & \\
\hline \multicolumn{5}{|c|}{ Ursolic acid } \\
\hline 0 & 1.005 & 0.0000 & $1.3179 \pm 0.01051$ & \multirow[t]{4}{*}{98.65} \\
\hline 1 & 1.003 & 0.1000 & $1.4126 \pm 0.01067$ & \\
\hline 2 & 1.002 & 0.2000 & $1.5204 \pm 0.01051$ & \\
\hline 3 & 1.005 & 0.3000 & $1.6108 \pm 0.01256$ & \\
\hline
\end{tabular}

*Mean \pm S.D. $(\mathrm{n}=7)$

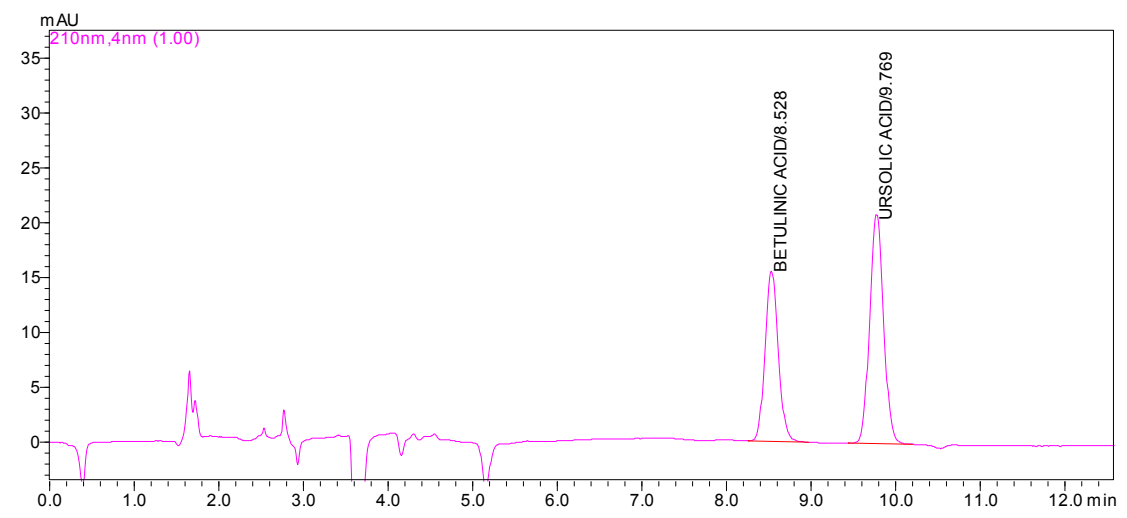

Figure 1: HPLC chromatograms obtained for mixture of standard betulinic acid and standard ursolic acid

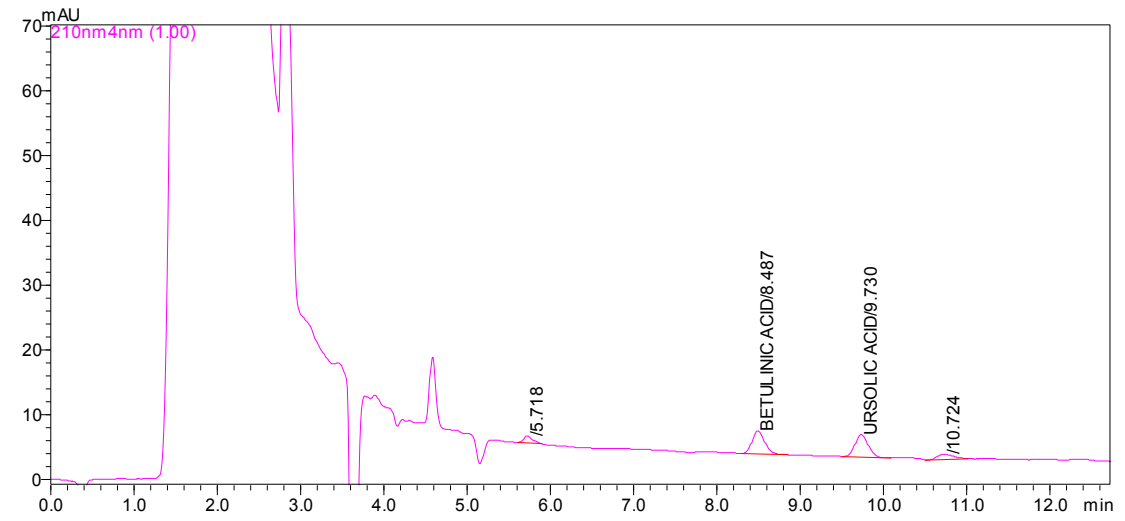

Figure 2: HPLC chromatograms obtained for methanolic extract of dry stem bark powder of Mimusops elengi Linn. 
The identity of the peaks of betulinic acid and ursolic acid in the sample solutions was confirmed by comparing their retention times in sample with that of reference standards. The retention time for betulinic acid and ursolic acid in sample solutions were 8.48 minutes and 9.73 minutes respectively. Figure 1 shows typical HPLC chromatogram of standard betulinic acid, standard ursolic acid and Figure 2 shows chromatographic separation of betulinic acid and ursolic acid in methanolic extract of dried stem bark powder of Mimusops elengi Linn. The developed method provided a good separation of the phytochemicals with the resolution $\left(\mathrm{R}_{\mathrm{S}}\right)$ of 4.130 , whereas the tailing factors were 1.258 and 1.161 for betulinic acid and ursolic acid respectively. The resolution and tailing factor values lies between the acceptable limits.A reverse phase HPLC method has been developed for the separation of three triterpene acids betulinic acid, ursolic acid and oleonic acid $^{14}$. The separation was carried on C18 Silica Lichrospher 100RP-18 column (125 x 4mm, $5 \mu \mathrm{m})$ using mobile phase of acetonitrile: $0.02 \mathrm{M}$ phosphate buffer $\mathrm{pH}=3.5+7.5 \mathrm{mM} H \mathrm{HP}-\gamma-\mathrm{CD}$ in the volume ratio of 70.0:30.0 with the flow rate of $1.0 \mathrm{~mL} / \mathrm{minute}$. The detection was done at $\lambda=225 \mathrm{~nm}$. The retention times of betulinic aid and ursolic acid were 5.0 minutes and 13.0 minutes respectively. Another HPLC method has been reported for identification of betulinic acid and ursolic acid from apple ${ }^{15}$. The separation was achieved on Develosil RP aqueous column $(250 \mathrm{x} 4.6 \mathrm{~mm}$, $5 \mu \mathrm{mPhenomenex}$ ). Gradient programming of the mobile phase was developed. The flow rate of the mobile phase was $1.5 \mathrm{~mL} /$ minute with a gradient starting at methanol: water (v/v; containing $0.1 \%$ trifluoroacetic acid (TFA), increasing the methanol (+0.1TFA) concentration to $100 \%$ within 60.0 minutes and keeping that concentration constant for 10.0 minutes. The detection was done at $\lambda=210 \mathrm{~nm}$. The retention times of betulinic acid and ursolic acid were 19.0 minutes and 22.0 minutes respectively. The mobile phase selected for the present research study is water: acetonitrile $(88.0: 12.0 \mathrm{v} / \mathrm{v})$. The selected mobile phase in the present research work is advantageous as compared to the reported mobile phases. In all the methods reported above, complicated solvent systems have been used as the mobile phase but in the developed method the mobile phase is isocratic system and is simpler. The developed method is simpler than the reported methods. In the developed method the retention times of betulinic acid and ursolic acid were less as compared to reported retention times. In the present research work, the developed HPLC method was validated using ICH guidelines and using the method; betulinic acid and ursolic acid were quantitated. The developed HPLC method is simple and fast as compared to the HPLC methods reported in the literature.

\section{CONCLUSION}

The developed HPLC technique is precise, specific and accurate and can be used for the routine quality control analysis and simultaneous quantitative determination of betulinic acid and ursolic acid from the dried stem bark powder of Mimusops elengi Linn.

\section{ACKNOWLEDGMENTS}

Authors wish to thank Dr. P. S. Ramnathan Advanced Instrumentation Centre, Chemistry Department, Ramnarain Ruia College, for providing instrument facilities to carry out the research work.

\section{REFERENCES}

1. Biswas T, Mukherjee B.Plant Medicines of Indian Origin for Wound Healing Activity: A Review, Int J Low Extrem Wounds 2003; 2(1): 25-39.http://dx.doi.org/10.1177/1534734603002001006 PMid: 15866825

2. Gupta N, Jain UK. Investigation of wound healing activity of Methanolic extract of stem bark of Mimusops elengi Linn. AJTCAM2011; 8(2): 98-103. PMid:22238490 PMCid:PMC32 52694

3. Ganu $\mathrm{G}$, Jadhav $\mathrm{S}$. In vitro antioxidant and In vivo antihyperglycemic potential of Mimusopselengi L. In Alloxan induced diabetes in mice. JCIM 2010;7(1):1-13.

4. Ashok P, Koti B, Vishwanath swamy AHM. Antiurolithiatic and antioxidant activity of Mimusops elengi on ethylene glycol induced urolithiasis in rats. IJP 2010; 42(6): 380-383.

5. Rao KS, Munjuluri PR, Keshar NK. In vitro antioxidant activity and total phenolic content of Mimusops elengi Bark. IJPER 2011 45(4):317-323.

6. Jerline M, Jothi G, Brindha P. Effect of Mimusops elengi Linn. bark extract on Alloxan induced Hyperglycemia in albino rats. TCR 2009; 9(3): 1985-1988

7. Rangama BNLD, Abayasekara CL and Panagoda GJ. Antibiotic Activity of Tephrosia purpurea (Fabaceae) and Mimusops elengi (Sapotaceae) against some Clinical Bacterial Isolates. Proceedings of the Peradenia University Research Sessions 2007; 12(1):55-56.

8. Quality standards of Indian Medicinal plants. New Delhi: Indian Council for Medicine and Research; 2005.p. 161-167.

9. Perumal Y, Dharmarajan S.Betulinic Acid and Its Derivatives: A Review on their Biological Properties. Curr. Med. Chem 2005; 12 : 657-666. http://dx.doi.org/10.2174/0929867053202214

10. Akowuah GA, Zhari I. Determination of Betulinic Acid from Orthosiphon stamineus leaf extract in rat plasma. Pharmazie 2008, 63: 788-790. PMid:19069237

11. Goretti M. et al. Variation in Ursolic acid content in eight Ocimum Species from North-eastern Brazil. Molecules 2008; 13: 2482 2487.http://dx.doi.org/10.3390/molecules13102482 PMid:18923339

12. Liao Q, Yang W, Jia Y, Chem X. LC-MS Determination of and Pharmacokinetic studies of Ursolic acid in Rat Plasma after administration of the Traditional Chinese Medicinal Preparation LuYing Extract, Yakugaku Zasshi 2005; 125(6): 509-515.http:// dx.doi.org/10.1248/yakushi.125.509 PMid:15930819

13. $\mathrm{Du} \mathrm{H}$, Chen XQ.A Comparative Study of the Separation of Oleanolic Acid and Ursolic Acid in Prunella vulgaris by HighPerformance Liquid Chromatography and Cyclodextrin-Modified Micellar Electrokinetic Chromatography. JICS 2009; 6(2): 334-340. http://dx.doi.org/10.1007/BF03245842

14. Claude B et.al. Evaluation of apparent formation constants of pentacyclic triterpene acid complexes with derivatized $\beta$ - and $\gamma$ cyclodextrins by reverse phase liquid chromatography. J. Chromatogr. A 2004; 1049:37-42. http://dx.doi.org/10.1016 /j.chroma.2004.06.133 PMid:15499915

15. Jager S. Pentacyclic triterpene distribution in various plants rich sources for a new group of multi-potent plant extracts. Molecules 2009; 14: 2016-2031.http://dx.doi.org/10.3390/molecules14062016 PMid:19513002

16. Mukherjee P. Quality Control of Herbal Drugs-An Approach to Evaluation of Botanicals. $1^{\text {st }}$ Ed. New Delhi: Business Horizons Pharmaceutical Publisher; 2008. p. 116.

Cite this article as:

Vidya Dighe, Dhanashri Mestry. High performance liquid chromatographic method for simultaneous quantitation of betulinic acid and ursolic acid from dried stem bark powder of Mimusops elengi Linn. Int. J. Res. Ayurveda Pharm. 2013;4(6):899-902 http://dx.doi.org/ $\underline{10.7897 / 2277-4343.04625}$ 